Запропоновано метод оцінювання часу проекту, заснозамість $\beta$-розподілу. Запропонована модифікація PERT, яка дозволила долучити до оцінки якість експерта та спростити процедуру експертизи. Запропонований новий метод оцінки часу проекту, заснований на властивостях розподілу Релея, та беручий до уваги особливості сучасних методів формування сітьового графіку у IT-проектах з високим ступенем деталізації робот при наявній можливості непередбачуваного затягування часу виконання окремих робот. Проведене порівняння тръох різних методів оцінки часу проекту, що грунтуються на двох різних статистиках та двох різних методах обчислення часу проекту Порівняння проводилося з метою пошуку методу найбільш простого з точки зору збору інформачії та гідного для алгоритмічної реалізащї.

Показано, що результат оцінювання краще збігається з особливостями складних IT-проектів та дає можливість скоротити кількість ітерацій за час виконання проекту, а також використовувати об'єктивну оцінку головних чинників помилок визначення часу, даючи оцінку з заданою наперед вірогідністю. Показано, що оцінка найбільш вірогідного та мінімального часу проекту при розрахунку за новим методом узгоджується з результатами розрахунку за методом PERT, у той же час оцінка максимального часу відрізняється сильно - новий метод більи песимістичний у иьому сенсі, $і$ це краще узгоджується з особливостями складних ІТ-проектів, які мають високу вірогідність несподіваних затримок під час виконання. Зроблені висновки про можливість використання результатів при створенні системи оцінки часу проекту на основі методів итучного інтелекту та виявлені параметри для налаштування такої системи

Ключові слова: РЕRT, оцінювання часу виконання проекту, якість експерта, джерела помилок оцінювання

\section{MODIFICATION OF THE PERT METHOD FOR PROJECT TIME EVALUATION TAKING INTO ACCOUNT UNEXPECTED DELAYS}

\author{
V. Litvinov \\ $\mathrm{PhD}$, Associate Professor \\ Department of Information Technologies of \\ Design in Mechanical Engineering \\ Industrial Technologies, Design and \\ Management Institute* \\ E-mail: litv@te.net.ua \\ A. Moskaliuk \\ $\mathrm{PhD}$ \\ Department of \\ Systems Management Life Safety* \\ E-mail: Andreum@mail.ru \\ *Odessa National Polytechnic University \\ Shevchenka ave., 1, Odessa, Ukraine, 65044
}

\section{Introduction}

In the process of implementation of a project in various fields, there is always the same question: how realistic the claimed project implementation terms are and how much actual terms will differ from the claimed terms. For IT-projects, correct assessment of execution time is a key factor in the success of a project in general. Projects are often executed in the face of stiff competition for market share, the delay in the completion of a project, in comparison with the projects competitors, often devalues the whole work, while timely completion and successful entry into the market can ensure the future of the company-developer.

The terms and the budget of a project are usually discussed at the outset of a project. The project manager relies on the project team, he can involve additional specialists and can simultaneously manage several projects with one team. Under such sufficiently real conditions, it is necessary to assess carefully the labor intensity of each operation, consistency and the possibility of parallelization. The evaluation results are usually represented in the form of network charts and Gantt diagrams with the subsequent analysis of these preliminary documents. The project manager cannot be an expert in all areas that are to be developed, that is why labor intensity and evaluation of implementation time are usually made by employees themselves. The project manager brings the data together, parallelizes work, where possible, and ensures that the project could be completed in due time. To control as many parameters as possible, the network diagram is constructed with the greatest possible detailing, performers need to normalize many minor works, related to each other.

Development of project management required formalization of the methods for project time calculation. The studies were conducted both to develop the methods for formalization of the project time calculation procedure and with a view to determining the mechanisms that affect implementation time. Much attention was paid to the sources of errors, associated with the statistical distribution, used in the calculation method. In this case, finite distributions were mainly considered, while truncated distributions were 
excluded from consideration, although calculation accuracy was low for finite distributions. The approach was formed, in which the original data for calculation were obtained through a survey of direct executors, and terms of works and of a project in general were calculated based on these methods with the use of statistical methods. For complex projects that contain a large amount of innovation, this approach does not always provide adequate assessment, it does not take into consideration the influence of unforeseen factors causing delays on specific tasks and the project in general. In addition, this approach gives an expert the role of an interpreter, while a highly skilled expert is able to assess more accurately the working time of a direct executor, because he is aware of a greater number of completed projects. Moreover, the work of an expert can be formalized and form the basis for an expert system. In the light of the rapid development of expert systems, the problem seems quite relevant; its solution will make a qualified assessment of project execution time more accessible.

\section{Literature review and problem statement}

To estimate the time of project implementation, the method for project evaluating and reviewing PERT (Project Evaluation and Review Technique) was developed in 1958. Its modifications in line with modern computing capabilities appeared later [1]. According to this method, the project network diagram is constructed, the critical path is found and time of its completion is evaluated under the assumption that the time of completion of each operation on this path is approximated by $\beta$-distribution. Modifications involved not only the basic method, but also the critical path method, adding the possibilities of its optimization [2].

Author [3] studied the possibility of passing from the three-point evaluation of the project time to the two-point evaluation (optimistic and pessimistic). Along the way, the technique for identifying possible errors of using different statistical distributions with the set goal was developed.

Three groups of errors were separated. The first group incorporates the errors associated with the selection of $\beta$-distribution as the basic one. The second group comprises the evaluation errors in the absence of errors of the first group. The third group is associated with expert errors of estimation of parameters $a, b$ and $m$ in the absence of errors of the first and second groups. It is clear that errors of the third group will prevail in the standard technique, and since the time of tasks is estimated by executors themselves, there will be a tendency to over-estimate $m$ and, as compensation, to underestimate $b$. In order to avoid the error of the third kind, it is necessary to attract an external expert to evaluation of time of works.

Further studies were carried out in the direction of involving the methods of mathematical statistics to solution of the problem [4], in particular, the Monte-Carlo method [5]. It was shown that both stochastic methods, based on Gaussian distribution, and the Monte Carlo method give a prediction error, similar to the PERT method [6], the same results were obtained for the method of hierarchies in a complex process [7]. In these works, an attempt was made to analyze the work of experts and identify the factors influencing their mistakes. The analysis resulted in the matrices of influence [8] of various factors on errors of experts. The Monte Carlo method was also applied to plot the project network diagram with identification of the critical path [9].
Based on influence matrices, it is possible to introduce the concept of expert examination equality. The higher the expert examination quality, the lower will be the coefficients in influence matrices, the less external factors will affect the outcome of the work of an expert. In this case, there arises the question of how to evaluate numerically the quality of work of an expert and whether it is possible to determine this magnitude a priori, before the examination.

To solve the problem of enhancing the accuracy of project time estimation, the methods of artificial intelligence, in particular, of neural networks, were involved [10]. Along the way, it was possible to raise the accuracy of project time estimation up to $87 \%$ through consistent training. This is a promising result - during construction of an expert system on the methods of artificial intelligence, it is necessary to provide sufficient flexibility to management and learning, then the accuracy of estimation can be increased to the required level and it will be possible to completely avoid human errors and to have preliminary assessment for other errors.

Non-deterministic nature of the problem became a natural basis for the use of fuzzy logic methods. The methods were used both for construction of fuzzy neural networks [11, 12], and for organization of fuzzy computational procedures, based on the PERT method [13].

Despite considerable progress in studies, the problems relating criteria for selection of basic distribution of a random magnitude were not sufficiently explored. Neither was the problem of how involvement of third-party experts with various qualifications affects the process in terms of the error they bring into the result.

\section{The aim and objectives of the study}

The aim of this study is to develop a modified method for determining the execution time of separate tasks and a whole project based on the Rayleigh distribution in comparison with the classical PERT method. The results are planned to be used during construction of the algorithmic system of evaluation of the project execution time using the methods of artificial intelligence.

To achieve the set aim, the following tasks were to be solved:

- to compare the methods based on model distribution and those based on Rayleigh distribution;

- to show that the method of project time evaluation, based on Rayleigh distribution, makes it possible to take into consideration unforeseen delays with the probability that was assigned beforehand;

- to assess the possibilities to control the proposed method by using a limited number of parameters, with the purpose of training an expert system.

\section{Substantiation and analysis of the modified method of project time evaluation}

It was shown [14] that the $\beta$-distribution corresponds to the following model of the process, which started at moment $T_{0}$ and finished at moment $\tau$ in the interval $T_{1}$ and $T_{2}$, where $T_{1}$ corresponds to the absence of delays, and $T_{2}$ corresponds to the case of the largest number of delays:

1. Time of work $T_{1}-T_{0}$ is partitioned into $n$ small time intervals of the same duration, the longest possible time of 
delay $T_{2}-T_{1}$ is partitioned into the same number $\mathrm{n}$ of equal intervals of different duration.

2. Intervals of delays are between the work intervals, in this case, after the work interval, there can start the following work interval or the delay interval, but not vice versa. Depending on the number of the implemented delays, the time of work changes from $T_{1}$ (no delays) to $T_{2}$ (all delays were implemented).

3. Events, leading to delays, make up a certain general totality of events, each $i$-th element of which contains probability $p_{i}$ of delay emerging after the $i$-th element of work. This totality increases by $\theta$ after each stage of the process, where $\theta$ is the number of the implemented delays.

4. We consider such law of delays, for which the relative magnitude of delays is constant.

For the probabilistic PERT, the following assumptions hold:

1. Duration of arbitrary work $t(i, j)$ is a random magnitude, which obeys the law of $\beta$-distribution on section $[a, b]$ with probabilistic density of:

$$
f(t)=C(t-a)^{\alpha-1}(b-t)^{\beta-1} .
$$

2. Mathematical expectation $M(i, j)$ and variance $\sigma^{2}(i, j)$ of distribution $f(t)$ are derived from formulas:

$$
\begin{aligned}
& M(i, j)=\frac{a_{i j}+4 m_{i j}+b_{i j}}{6}, \\
& \sigma^{2}(i, j)=\frac{\left(b_{i j}-a_{i j}\right)^{2}}{36},
\end{aligned}
$$

or more roughly

$$
\sigma^{2}(i, j)=\frac{\left(b_{i j}-a_{i j}\right)}{6},
$$

where $a_{i j}, b_{i j}, m_{i j}$ are the estimates of time of work $(i, j)$ for pessimistic, optimistic and most probable scenario of its execution. Expressions (4) and (5) were derived through imposing even more rigid constraints on distribution parameters. These constraints are based on the experience of PERT developers, do not have any theoretical substantiation, which makes expressions for mathematical expectation and dispersion half-empirical.

If we consider the normalized range:

$$
a=0, b=1.0, m^{\prime}=(m-a) /(b-a)<1 / 2,
$$

the maximum absolute error of mathematic expectation $M_{x}$ :

$$
\Delta_{1}=\frac{1}{3}\left(1-2 m^{\prime}\right),
$$

and the maximum absolute error of root-mean-square deviation $\sigma_{x}$ :

$$
\Delta_{2}=\frac{1}{6}
$$

At assumptions (2) and (4), errors of the second group can be determined from expressions (5) and (6), in this case, the maximum value of errors in the normalized range will make up $\Delta_{1 \max }=33 \%$ and $\Delta_{2 \max }=17 \%$ :

$$
\begin{aligned}
& \Delta_{1}=\left|\frac{4 m^{\prime}+1}{6}+\frac{m^{\prime}(a+1)}{a+2 m}\right| ; \\
& \Delta_{2}=\left|\frac{1}{6}-\sqrt{\frac{m^{\prime 2}(a+1)\left(a-a m^{\prime}+m^{\prime}\right)}{\left(a+2 m^{\prime}\right)^{2}\left(a+3 m^{\prime}\right)}}\right| .
\end{aligned}
$$

Considering the errors of the third group, we believe that estimates $a, b, m$ are true and the duration of the process obeys $\beta$-distribution, then we introduce arbitrary intervals of errors for expert estimations $t_{a}, t_{b}, t_{m}$, such as:

$0.8 a \leq t_{a} \leq 1.1 a ; 0.9 m \leq t_{m} \leq 1.1 m ; 0.9 b \leq t_{b} \leq 1.2 b$

and additional condition:

$$
a \leq m \leq \frac{a+b}{2} .
$$

In this case, the worst absolute estimations of errors will be:

$$
\begin{aligned}
& \Delta_{1}=\frac{1}{b-a} \max \left[\mid \begin{array}{l}
\left|\frac{(0.8 a+3.6 m+0.9 b)-(a+4 m+b)}{6}\right|, \\
\left|\frac{(1.1 a+4.4 m+1.2 b)-(a+4 m+2 b)}{6}\right|
\end{array}\right]= \\
& =\frac{1}{60} \frac{a+4 m+2 b}{b-a}
\end{aligned}
$$

$$
\Delta_{2}=\frac{1}{b-a} \max \left[\begin{array}{l}
\left|\frac{0.9 b-1.1 a-(b-a)}{6}\right|, \\
\left|\frac{(1.2 b-0.8 a)-(b-a)}{6}\right|
\end{array}\right]=\frac{1}{30} \frac{b+a}{b-a} .
$$

In this case, distribution mode $\mathrm{m}$ does not affect the error of standard deviation $\Delta_{2}$.

Due to non-eliminable contradictions in the method of calculating the parameters of time estimation distribution, repeated attempts were made to modify the PERT method in order to eliminate or at least soften controversies.

The method was initially based on two a priori assumptions:

1. Probability of duration of execution of any work is described by $\beta$-distribution and execution time is restricted by the interval from an optimistic $(a)$ to a pessimistic $(b)$ evaluation of execution time.

2. The standard deviation of this $\beta$-distribution is $1 / 6$ of the span.

The first assumption is the statement of the seemingly obvious fact that any work will end sooner or later. But for complex projects involving a large amount of pioneering research, it is absolutely not clear.

Work can give a negative result or be transformed into a separate project, and in this case it is necessary to reorganize the project so as to get the final result in a different way, using different methods and developments. In this case, it is possible to speak about deadline for work 
completion, after which there must be decided to finalize the work or change its composition. The work itself in its original sense can remain incomplete, and the term of its completion - uncertain.

The second assumption should follow from the first. From the most general considerations, standard deviation for unimodal limited distributions can be roughly estimated as $1 / 6$ of the span. That is, the second assumption follows from the first. However, such an assumption in mathematical statistics can prove to be false. Thus, for the uniform distribution on interval $(a, b)$ :

$$
\sigma^{2}=\frac{b-a}{2 \sqrt{3}}
$$

With a little distortion of probability density, this distribution can be made unimodal by retaining the magnitude of the standard deviation. Now suppose that two independent random magnitudes are determined on interval $(a, b)$ each. Due to assumptions 2, standard deviation of the sum of these magnitudes can be described by expression:

$$
\sigma^{2}=\sqrt{2} \frac{b-a}{6}
$$

But the sum is determined on interval $(2 a, 2 b)$ and based on assumption 2, its standard deviation must be equal to $(2 b-2 a) / 6$.

Hence, it follows that assumption 2 in this case does not hold.

To eliminate the contradictions, it was proposed to use other distributions, for example, gamma-distribution

$$
f(t)= \begin{cases}\frac{\delta^{\lambda} t^{\lambda-1} e^{-\delta t}}{\Gamma(\lambda)}, & (0<t\langle\infty ; \delta, \lambda\rangle 0), \\ 0, & t \leq 0 .\end{cases}
$$

The benefit of this function is the fact that in order to determine its parameters, we need two time evaluations, which are proposed to be determined by certain intermediate quantiles.

The same approach with the use of quantiles was also proposed for $\beta$-distribution. It was pointed out that the correct use of quantiles poses difficulties for an inexperienced user on flat sections of distribution, a small change in value $p$ leads to a significant change in value $W_{p}$.

The search for distributions, suitable for this task, led to logarithmically normal distribution:

$$
p(x)= \begin{cases}\frac{1}{\sigma\left(x-t_{1}\right) \sqrt{2 \pi}} \exp \left[-\frac{\ln \left(x-t_{1}\right)-r^{2}}{2 \sigma^{2}}\right] & \text { at } x>t_{1}, \\ 0 & \text { at } x \leq t_{1} .\end{cases}
$$

Based on a statistical analysis of a large number of project models, it was found that for values $r$ and $\sigma=0.5$, lognormal distribution will have the form:

$$
p(x)=\frac{\sqrt{2}}{\sqrt{\pi}(x-a)} e^{-2\left[\ln \left(x-t_{1}\right)-\ln \left(t_{2}-t_{1}\right)+1\right]^{2}} \text { at } x>a .
$$

It approximates well the distribution of work execution time, but is based on only two estimations, assigned by executors of work $t_{1}$ and $t_{2}$.

The parameters of this distribution in the specified case will take the form, shown in Table 1.

Errors of the second kind are equal to $\Delta_{1}=40 \%$ and $\Delta_{2}=20 \%$, respectively.

In a large project of IT-area, the network diagram can be very complicated due to a large number of operations and their reciprocal influence. Thus, some decision, obtained at early stages of a project, can be introduced at later stages in other operations and lead to their significant changes, both in essence and terms. On the other hand, some part of tasks might give a negative result, and they will have to be refocused to other methods, which would result in additional works with consumption of additional resources and time.

In the process of plotting a network diagram, there is a natural desire to make it as detailed as possible to get the most accurate estimates of execution time. Dividing each operation into its components, we will eventually get separate components that do not have a distinct structure. That is why they cannot be divided into parts. In this case, it is natural to believe that internal processes of each such indivisible operation are subject to normal distribution and are sufficiently independent that is orthogonal. Internal processes are summed up and generate an operation, the time of execution of which will already have Rayleigh distribution (14):

$$
f(x ; \sigma)=\frac{x}{\sigma^{2}} \exp \left(-\frac{x^{2}}{2 \sigma^{2}}\right), \quad x \geq 0 ; \quad \sigma>0,
$$

probability density of which is determined from expression (15):

$$
F(x, \sigma)=1-\exp \left(-\frac{x^{2}}{2 \sigma^{2}}\right)
$$

and mode $m$ and mathematical expectation $M$, respectively,

$$
m=\sigma, \quad M=\sqrt{\sigma(\pi / 2)} .
$$

This conclusion, in particular, is proved by research [5], in which, based on the analysis of a large number of projects, it was concluded that the Gaussian model of processes is suitable most precisely for predictions of the time of execution of project operations.

Table 1

Parameters of distribution of time of project works execution

\begin{tabular}{|c|c|c|c|c|}
\hline \multirow{2}{*}{ Mode } & \multirow{2}{*}{ Mathematic expectation } & Dispersion & \multicolumn{2}{|c|}{ Maximum error } \\
\cline { 3 - 4 } & & of mathematic expectation & of standard deviation \\
\hline$m \sim \frac{2.5 t_{1}+t_{2}}{3.5}$ & $M \sim \frac{1.4 t_{1}+t_{2}}{2.4}$ & $D \sim 0.04\left(t_{2}-t_{1}\right)$. & $a=0, b=1, m^{\circ}=\frac{m-a}{b-a}, \Delta_{1}=\left|m^{\circ}-0.4\right|$ & $\Delta_{2}=0.2$ \\
\hline
\end{tabular}


In accordance with basic formula (2), the PERT method transforms the data of expert estimation and, therefore, brings own errors in them. The proposed method does not transform the data of an expert and makes no error in assessing the most probable time of project completion. The error of minimum and maximum time is determined by the quality of expert examination and the delay probability, assigned beforehand.

Summing up the above, we define the new method as follows.

Application area - calculation of time of execution of complex projects with a large research component and a high degree of network diagram detailing.

The aim is to obtain the project time estimation, based on the work of a third-party expert with an assigned probability of unforeseen delays.

The essence is that the method uses one-point assessment of the work interval. An expert assesses the most probable time of completion of each task, the most probable time of execution at each moment is determined by the sum of the most probable times of work on the critical path. The minimum and maximum time will be obtained by matching standard deviation $\sigma$ to the quality of work of an expert, and quantile $p$ - with probability of estimation:

$$
\begin{aligned}
& a=\sigma * \sqrt{2 *(-\ln p)}=K_{a}^{*} \sigma, \\
& b=\sigma * \sqrt{2+(-\ln (1-p))}=K_{b} * \sigma \\
& T_{\min }=(1-a)^{*} T_{\text {exp }}, \\
& T_{\max }=(1+b)^{*} T_{\text {exp }},
\end{aligned}
$$

where $T_{\min }$ is the minimum estimated time of work execution, $T_{\max }$ is the maximum estimated time of work execution, $T_{\text {exp }}$ is the estimating of an expert of time of work execution. The simplicity of the procedure and possibility of adjustment by bases of completed projects makes it possible to speak about the prospects of construction of the expert system with described algorithm at its base and possibility to refuse from a highly qualified expert to obtain a high-quality estimation of the project execution time.

The objective basis is the fact that at high detalization of a network diagram, the processes, affecting the deviation of time of execution of each task, have a random nature, are independent and distributed according to the normal law. Because of this, the time of execution of each work has the Rayleigh law of distribution. The time of each work and of the whole project should be determined by a third-party expert who will not bring personal factors into the estimated parameters. If we accept the Rayleigh distribution as the basis, there is no need for more than one parameter to determine the time of work and accuracy of determining is a complete responsibility of an expert and is determined by his quality. In first approximation, Rayleigh distribution describes well the possibility of unforeseen delays, and through introducing the quantile of distribution, we can assign the probability of the obtained estimation.

The main rules (conditions) are that the network diagram of the project must have extremely high detailization so that the processes within each work should be independent. The expert should have a quality estimate, calculated based on the examinations of completed projects that he performed.
For numerical analysis of different approaches, we will create a model of the project and before the beginning of works, we will determine a critical path, consisting of 9 sequentially performed operations.

We assume that at each moment there is only one critical path. For this assumption, simple ratios for calculation of the optimistic and pessimistic time frames for the implementation of each operation based of expert evaluation of the terms were determined. The resulting estimates of minimum and maximum project execution time are obtained by summing up the optimistic and the pessimistic terms, respectively. The procedure is supposed to be repeated often enough, as soon as project operations are completed, and in this way to obtain more and more accurate estimate of the term as we approach the project completion.

As separate operations are completed, the critical path can change due to the fact that some operations were rated incorrectly, in this case, each operation may change in one or another direction. In specifying iterations after the initial iteration, the newly obtained expert estimates can differ greatly from the original ones.

\section{Modeling of project time estimates}

Modeling was performed in 3 stages. At stage 1, the classic PERT method was used and subsequently, results of stage 1 were used for comparison. At stage 2, the PERT ratios were used and applied to the data, distributed by Rayleigh, and at stage 3, statistics of Rayleigh distribution were used to determine the time of operations, showing the variability of results, depending on distribution parameters.

The data on changes in coefficients $K a$ and $K b$ at $\sigma$ for calculation of $a$ and $b$ are shown in Table 2 .

Table 2

Coefficients for calculation of minimum and maximum time

\begin{tabular}{|c|c|c|}
\hline$p$ & $K a$ & $K b$ \\
\hline 0.01 & 0.141776838 & 3.034854259 \\
\hline 0.05 & 0.320291412 & 2.447746831 \\
\hline 0.07 & 0.380974259 & 2.306191682 \\
\hline 0.1 & 0.459043605 & 2.145966026 \\
\hline 0.2 & 0.668047231 & 1.794122578 \\
\hline 0.3 & 0.844600431 & 1.551755654 \\
\hline 0.4 & 1.010767653 & 1.353728726 \\
\hline 0.5 & 1.177410023 & 1.177410023 \\
\hline 0.6 & 1.353728726 & 1.010767653 \\
\hline
\end{tabular}

Distribution boundaries are unambiguously related to its parameter $\sigma$, the errors of determining the boundaries of the error will be proportional to the error of standard deviation.

A similar result can be obtained due to the known tendency that some operations in a project are completed within the term, by far exceeding the planned term or are not completed for objective or subjective reasons, and the project requires adjustment of the structure in the process of its implementation.

Let us compare results of modeling. We will consider as a basic model the estimation of the network diagram by the PERT method in the first iteration. 
Let us assume that on the critical path, there are 9 operations, parameters of which are obtained through an expert survey, are summarized in Table 3, columns 1-4.

Table 3

Calculation by the classic PERT model

\begin{tabular}{|c|c|c|c|c|}
\hline \multirow{2}{*}{$\begin{array}{c}\text { No. of } \\
\text { operation }\end{array}$} & \multicolumn{4}{|c|}{ Time of project execution, days } \\
\cline { 2 - 5 } & Expert & Minimum & Maximum & Estimated \\
\hline 1 & 3 & 2 & 4 & 2.5 \\
\hline 2 & 6 & 4 & 10 & 5.3 \\
\hline 3 & 43 & 35 & 55 & 39.7 \\
\hline 4 & 17 & 14 & 21 & 15.7 \\
\hline 5 & 22 & 21 & 23 & 21.5 \\
\hline 6 & 35 & 25 & 45 & 30 \\
\hline 7 & 55 & 44 & 58 & 48.2 \\
\hline 8 & 63 & 51 & 72 & 56.5 \\
\hline 9 & 18 & 15 & 20 & 16.3 \\
\hline Total & 262 & 211 & 308 & 235.7 \\
\hline
\end{tabular}

Then, using the technique, described in [1], in column 5, we will obtain estimated time of each operation. Let us consider the same model, but accept Rayleigh distribution as working. We will use the following considerations, in this case, we will take into account that the evaluation was made by an expert. Based on modern requirements, the level of detailing the network diagram should be high. In this case, the error of estimation of the time for a particular operation will be determined by the qualifications of an expert, the possibility and actual consideration of all possible external and internal influences by an expert.

All this can be united by the generic term «estimation accuracy of a particular expert» and treated as mean deviation of an estimate from the actual a posterior value. For Rayleigh distribution, we will formalize this magnitude as normalized standard deviation of estimate $\sigma$.

Suppose that the expert has $\sigma=0.1$, we will set the cutoff level during determining the maximum time as equal to 0.1 . The minimum time will be determined as $-\sigma$ from the most probable value (expert estimation), the maximum time will be determined by cutoff quantile, and the estimated time will be derived from formula from the PERT method (4).

Table 4

Calculation by the mixed model 1

\begin{tabular}{|c|c|c|c|c|}
\hline \multirow{2}{*}{$\begin{array}{c}\text { No. of } \\
\text { operation }\end{array}$} & \multicolumn{4}{|c|}{ Project execution time, days } \\
\cline { 2 - 5 } & Expert & Minimum & Maximum & Estimated \\
\hline 1 & 3 & 3 & 11 & 4 \\
\hline 2 & 6 & 5 & 23 & 9 \\
\hline 3 & 43 & 39 & 163 & 62 \\
\hline 4 & 17 & 15 & 65 & 25 \\
\hline 5 & 22 & 20 & 84 & 32 \\
\hline 6 & 35 & 32 & 133 & 51 \\
\hline 7 & 55 & 50 & 209 & 80 \\
\hline 8 & 63 & 57 & 239 & 91 \\
\hline 9 & 18 & 16 & 68 & 26 \\
\hline Total & 262 & 236 & 996 & 380 \\
\hline
\end{tabular}

The estimated time, determined by the PERT method with the use of Rayleigh distribution, gives the time estimate that is more pessimistic compared with model distribution.
Certainly, we can argue that formula (4) is not very suitable for calculation of mathematical expectation of Rayleigh distribution. Previously, it was shown that for model distribution, this formula is rather a compromise between accuracy and simplicity of computation with a clear shift towards simplicity.

With an increase in parameter $\sigma$ for an expert, calculated estimate will approach the expert estimate, retaining the «pessimistic» trend. Thus, for $\sigma=0.03$ and for the same source data, we will obtain the following calculated values, shown in Table 5 that are reasonably close to evaluation by model distribution.

Table 5

Calculation by mixed model 2

\begin{tabular}{|c|c|c|c|c|}
\hline \multirow{2}{*}{$\begin{array}{c}\text { No. of } \\
\text { operation }\end{array}$} & \multicolumn{4}{|c|}{ Project execution time, days } \\
\cline { 2 - 5 } & Expert & Minimum & Maximum & Estimated \\
\hline 1 & 3 & 3 & 4 & 3 \\
\hline 2 & 6 & 6 & 8 & 6 \\
\hline 3 & 43 & 42 & 163 & 46 \\
\hline 4 & 17 & 16 & 65 & 18 \\
\hline 5 & 22 & 21 & 84 & 23 \\
\hline 6 & 35 & 34 & 133 & 37 \\
\hline 7 & 55 & 53 & 88 & 58 \\
\hline 8 & 63 & 61 & 88 & 67 \\
\hline 9 & 18 & 17 & 25 & 19 \\
\hline Total & 262 & 254 & 367 & 278 \\
\hline
\end{tabular}

Let us move away now from the PERT technique for estimated time and use the properties of Rayleigh distribution. We will take into consideration the fact that the error of estimate is a result of the work of an expert, the quality of which is related to parameter $\sigma$ of distribution. Quantile $p$ will give us a probabilistic characteristic of the obtained evaluation of the interval $\left[t_{a}, t_{b}\right]$.

To assess the similarity of the results to those obtained using the PERT method, we will calculate normalized standard deviation of the points on the left and right distribution branches separately. We will use the value of the expert estimate of time of each operation as a normalization parameter.

Thus, for the same original data, an expert with assessment quality $\sigma=0.1$ and estimation probability of $90 \%$ (quantile $p=0.1$ ), we will obtain the result shown in Table 6 .

Table 6

Calculation by Rayleigh model 1

\begin{tabular}{|c|c|c|c|c|c|}
\hline \multirow{2}{*}{$\begin{array}{l}\text { No. of } \\
\text { operation }\end{array}$} & \multicolumn{3}{|c|}{ Project execution time, days } & \multicolumn{2}{|c|}{ RMS } \\
\hline & $\begin{array}{c}\text { Expert } \\
\text { estimate }\end{array}$ & $\begin{array}{l}\text { mini- } \\
\text { mum }\end{array}$ & $\begin{array}{l}\text { maxi- } \\
\text { mum }\end{array}$ & $\begin{array}{c}\text { minimum } \\
\text { time }\end{array}$ & $\begin{array}{c}\text { maximum } \\
\text { time }\end{array}$ \\
\hline 1 & 3 & 2.86 & 3.64 & 0.083 & 0.014 \\
\hline 2 & 6 & 5.72 & 7.29 & 0.083 & 0.204 \\
\hline 3 & 43 & 41.03 & 52.23 & 0.020 & 0.004 \\
\hline 4 & 17 & 16.22 & 20.65 & 0.017 & 0.000 \\
\hline 5 & 22 & 20.99 & 26.72 & 0.000 & 0.029 \\
\hline 6 & 35 & 33.39 & 42.51 & 0.058 & 0.005 \\
\hline 7 & 55 & 52.48 & 66.80 & 0.024 & 0.026 \\
\hline 8 & 63 & 60.11 & 76.52 & 0.021 & 0.005 \\
\hline 9 & 18 & 17.17 & 21.86 & 0.015 & 0.011 \\
\hline Total & 262 & 249.97 & 318.22 & 0.188 & 0.182 \\
\hline
\end{tabular}


For an expert with evaluation quality $\sigma=0.3$ and the same estimation probability of $90 \%$, we will obtain the set of values shown Table 7 .

Table 7

Calculation by Rayleigh model 2

\begin{tabular}{|c|c|c|c|c|c|}
\hline \multirow{2}{*}{$\begin{array}{c}\text { No. of } \\
\text { operation }\end{array}$} & \multicolumn{3}{|c|}{ Project execution time, days } & \multicolumn{2}{|c|}{ RMS } \\
\hline & $\begin{array}{c}\text { Expert } \\
\text { estimate }\end{array}$ & $\begin{array}{l}\text { mini- } \\
\text { mum }\end{array}$ & $\begin{array}{l}\text { maxi- } \\
\text { mum }\end{array}$ & $\begin{array}{l}\text { of mini- } \\
\text { mum time }\end{array}$ & $\begin{array}{l}\text { of maxi- } \\
\text { mum time }\end{array}$ \\
\hline 1 & 3 & 2.59 & 4.93 & 0.038 & 0.096 \\
\hline 2 & 6 & 5.17 & 9.86 & 0.038 & 0.001 \\
\hline 3 & 43 & 37.08 & 70.68 & 0.002 & 0.133 \\
\hline 4 & 17 & 14.66 & 27.94 & 0.002 & 0.167 \\
\hline 5 & 22 & 18.97 & 36.16 & 0.009 & 0.358 \\
\hline 6 & 35 & 30.18 & 57.53 & 0.022 & 0.128 \\
\hline 7 & 55 & 47.43 & 90.41 & 0.004 & 0.347 \\
\hline 8 & 63 & 54.32 & 103.56 & 0.003 & 0.251 \\
\hline 9 & 18 & 15.52 & 29.59 & 0.001 & 0.284 \\
\hline Total & 262 & 225.92 & 430.67 & 0.115 & 0.443 \\
\hline
\end{tabular}

Let us return now to the first expert and assign the estimation probability of $70 \%$ (quantile $p=0.3$ ) in Table 8 .

Table 8

Calculation by Rayleigh model 3

\begin{tabular}{|c|c|c|c|c|c|}
\hline \multirow{2}{*}{$\begin{array}{c}\text { No. of } \\
\text { operation }\end{array}$} & \multicolumn{3}{|c|}{ Project execution time, days } & \multicolumn{2}{|c|}{ RMS } \\
\hline & $\begin{array}{c}\text { Expert } \\
\text { estimate }\end{array}$ & $\begin{array}{l}\text { mini- } \\
\text { mum }\end{array}$ & $\begin{array}{c}\text { maxi- } \\
\text { mum }\end{array}$ & $\begin{array}{l}\text { of mini- } \\
\text { mum time }\end{array}$ & $\begin{array}{l}\text { of maxi- } \\
\text { mum time }\end{array}$ \\
\hline 1 & 3 & 2.75 & 3.47 & 0.062 & 0.032 \\
\hline 2 & 6 & 5.49 & 6.93 & 0.062 & 0.262 \\
\hline 3 & 43 & 39.37 & 49.67 & 0.010 & 0.015 \\
\hline 4 & 17 & 15.56 & 19.64 & 0.008 & 0.006 \\
\hline 5 & 22 & 20.14 & 25.41 & 0.002 & 0.012 \\
\hline 6 & 35 & 32.04 & 40.43 & 0.041 & 0.017 \\
\hline 7 & 55 & 50.35 & 63.53 & 0.013 & 0.010 \\
\hline 8 & 63 & 57.68 & 72.78 & 0.011 & 0.000 \\
\hline 9 & 18 & 16.48 & 20.79 & 0.007 & 0.002 \\
\hline Total & 262 & 239.87 & 302.66 & 0.155 & 0.199 \\
\hline
\end{tabular}

For expert with quality $\sigma=0.3$ and estimation probability of $70 \%$, we obtain the data collected in Table 9 .

Table 9

Calculation by Rayleigh model 4

\begin{tabular}{|c|c|c|c|c|c|}
\hline \multirow{2}{*}{$\begin{array}{c}\text { No. of } \\
\text { operation }\end{array}$} & \multicolumn{3}{|c|}{ Project execution time, days } & \multicolumn{2}{|c|}{ RMS } \\
\hline & $\begin{array}{c}\text { Expert } \\
\text { estimate }\end{array}$ & $\begin{array}{l}\text { mini- } \\
\text { mum }\end{array}$ & $\begin{array}{l}\text { maxi- } \\
\text { mum }\end{array}$ & $\begin{array}{l}\text { of mini- } \\
\text { mum time }\end{array}$ & $\begin{array}{l}\text { of maxi- } \\
\text { mum time }\end{array}$ \\
\hline 1 & 3 & 2.24 & 4.40 & 0.006 & 0.017 \\
\hline 2 & 6 & 4.48 & 8.79 & 0.006 & 0.040 \\
\hline 3 & 43 & 32.10 & 63.02 & 0.005 & 0.035 \\
\hline 4 & 17 & 12.69 & 24.91 & 0.006 & 0.053 \\
\hline 5 & 22 & 16.43 & 32.24 & 0.043 & 0.176 \\
\hline 6 & 35 & 26.13 & 51.29 & 0.001 & 0.032 \\
\hline 7 & 55 & 41.06 & 80.60 & 0.003 & 0.169 \\
\hline 8 & 63 & 47.04 & 92.33 & 0.004 & 0.104 \\
\hline 9 & 18 & 13.44 & 26.38 & 0.008 & 0.126 \\
\hline Total & 262 & 195.61 & 383.97 & 0.095 & 0.289 \\
\hline
\end{tabular}

The completed modeling stages make it possible to give a qualitative assessment of the proposed method. For a detailed analysis, additional calculations based on a database of completed projects will be required.

\section{Discussion of results of modeling the estimates of project time}

The classic PERT model, as expected, gives an estimate of project time, shifted toward less time than the time, required according to the expert opinion.

Calculations by the mixed model (Tables 5, 6), gave a shift in the evaluation towards more time compared to the time, given by the expert estimation, and demonstrate how a change in the parameter «quality of an expert» influences evaluation. For examination with higher quality, variation of values is less and the estimate of the most probable time approaches the expert evaluation. The following tables use the Rayleigh statistics, so the time estimation coincides with the expert estimation; in this case, it is interesting to what extent time estimates coincide with the classical estimates of minimum and maximum time.

Estimates of minimum time coincide quite exactly, and the estimate of maximum time is heavily influenced by the specified quality parameters of quality and quantile, moreover, in the higher quality examination, quantile affects the results less. This is well within the logic of the proposed method that expert examination of higher quality a priori more accurately takes into consideration unforeseen delays.

The results of the work show that for the projects related to scientific and technical developments, the use of Rayleigh distribution yields a more realistic result compared with model distribution. Maximum project time is shifted to the right, that is, unforeseen delays, remaining out of consideration in the classical method, are taken into account. It is possible to control the shift of maximum time by modifying the parameter of statistics, that is, the method can undergo the training procedure. Because of the use of one-parameter distribution, the method based on it is preferable for the algorithmic implementation, compared to other methods. The method gives the shift of estimates within $20 \%$ compared with the classical method, and this shift can also be controlled, which is also an advantage.

The narrowness of the model base can be attributed to the shortcomings of this research, as the studies were carried out with one model of a rather small size. This was done to demonstrate the new features of the method. Subsequently, it is necessary to use the available databases of the completed projects to fine-tune the model and to proceed to the development of the neural network for its implementation.

\section{Conclusions}

1. It was found that Rayleigh distribution can be used in the problem of determining the work completion time in complex IT-projects. Estimate error compared with model distribution varies within $20 \%$, at the same time the character of distribution takes into consideration the possibility of unforeseen delays, and makes it possible to assess their probability.

2. It was shown that the number of parameters required for calculation can be reduced due to the use of properties of Rayleigh distribution. This is substantiated by the fact 
that Rayleigh statistics better matches the internal processes of work when the highly-detailed network diagram is used and makes it possible to take into consideration unforeseen delays.

3. We determined parameters of settings the method of project time estimation that have statistical nature, but are related not to the internal mechanisms of a project, but rather to an expert, evaluating a project. This makes it possible to consider a calculation error as an examination error without analyzing other sources of errors, which greatly facilitates algorithmizing the expert's work. The results of this research can be used in construction of an expert system for evaluation of the project implementation time, and the use the setting parameters will enable its application in different domains.

\section{References}

1. Trietsch D., Baker K. R. PERT 21: Fitting PERT/CPM for use in the 21st century // International Journal of Project Management. 2012. Vol. 30, Issue 4. P. 490-502. doi: https://doi.org/10.1016/j.ijproman.2011.09.004

2. Anggara Hayun A. Perencanaan dan Pengendalian Proyek dengan Metode Pert - CPM Studi Kasus: Fly Over Ahmad Yani Karawang // The Winners. 2005. Vol. 6, Issue 2. P. 155. doi: https://doi.org/10.21512/tw.v6i2.605

3. Krivenkov Yu. P. Nekotorye voprosy teorii setevyh metodov planirovaniya // Kibernetika. 1968. Issue 2. P. 45.

4. Pearl R. G., Bowen P. A. Construction time prediction // Acta Structilia. 2002. Vol. 9, Issue 1. P. 1-12.

5. Comparison of Machine Learning Algorithms for Software Project Time Prediction / Han W. J., Jiang L. X., Lu T. B., Zhang X. Y. // International Journal of Multimedia and Ubiquitous Engineering. 2015. Vol. 10, Issue 9. P. 1-8. doi: https://doi.org/10.14257/ ijmue.2015.10.9.01

6. Kanoglu A. An integrated system for duration estimation in design/build projects and organizations // Engineering, Construction and Architectural Management. 2003. Vol. 10, Issue 4. P. 272-282. doi: https://doi.org/10.1108/09699980310489988

7. A prediction model for construction project time contingency / Mohamed D., Srour F., Tabra W., Zayed T. // Construction Research Congress 2009. 2009. P. 736-745. doi: https://doi.org/10.1061/41020(339)75

8. «Lifelong learning» is a new paradigm of personnel training in enterprises / Gogunskii V., Kolesnikov O., Kolesnikova K., Lukianov D. // Eastern-European Journal of Enterprise Technologies. 2016. Vol. 4, Issue 2 (82). P. 4-10. doi: https:// doi.org/10.15587/1729-4061.2016.74905

9. Pospieszny P., Czarnacka-Chrobot B., Kobylinski A. An effective approach for software project effort and duration estimation with machine learning algorithms // Journal of Systems and Software. 2018. Vol. 137. P. 184-196. doi: https://doi.org/10.1016/ j.jss.2017.11.066

10. Chao L.-C., Chien C.-F. A Model for Updating Project S-curve by Using Neural Networks and Matching Progress // Automation in Construction. 2010. Vol. 19, Issue 1. P. 84-91. doi: https://doi.org/10.1016/j.autcon.2009.09.006

11. Developing a Mathematical Model for Scheduling and Determining Success Probability of Research Projects Considering Complex-Fuzzy Networks / Norouzi G., Heydari M., Noori S., Bagherpour M. // Journal of Applied Mathematics. 2015. Vol. 2015. P. 1-15. doi: https://doi.org/10.1155/2015/809216

12. Time Prediction Using a Neuro-Fuzzy Model for Projects in the Construction Industry / Vahdani B., Mousavi S. M., Mousakhani M., Hashemi H. // Journal of Optimization in Industrial Engineering. 2016. Vol. 9, Issue 19. P. 97-103. doi: https://doi.org/10.22094/JOIE.2016.231

13. Using fuzzy logic to improve the project time and cost estimation based on Project Evaluation and Review Technique (PERT) / Habibi F., Taghipour Birgani O., Koppelaar H., Radenović S. // Journal of Project Management. 2018. P. $183-196$. doi: https://doi.org/10.5267/j.jpm.2018.4.002

14. Golsnko D. I., Shirvinskiy E. V., Ponomarev M. Primenenie statisticheskih metodov dli openki prodolzhitel'nosti rabot v sistemah SPU (na primere konstruirovaniya tipovyh blokov cifrovyh upravlyayushchih ustroystv) // Trudy 1 Vsesoyuznoy konferencii po matematicheskim metodam v SPU. Kyiv, 1967. 